\title{
E-Padi Berbasis Android Untuk Meningkatkan Minat Generasi Muda Pada Sektor Pertanian
}

\author{
Mambang ${ }^{1}$, Subhan Panji Cipta ${ }^{2}$, Finki Dona Marleny ${ }^{3}$, Nur Hafiz Ansari ${ }^{4}$, Akhmad Baddrudin ${ }^{5}$, Antonia \\ Yenitia $^{6}$, Dixky ${ }^{7}$, Melda $^{8}$, Nor Azizah ${ }^{9}$, Mutmainah ${ }^{10}$, Rizkian Muhammad Fikri11, Tasya Salsabila ${ }^{12}$ \\ Universitas Sari Mulia \\ Jl. PramukaNo. 02, Pemurus Luar,Kec. Banjarmasin Timur, Kota Banjarmasin, Kalimantan Selatan 70238 \\ Corresponding author: mmbg1283@gmail.com
}

\begin{abstract}
Abstrak - Sektor pertanian mempunyai peranan yang sangat penting dalam membangun perekonomian nasional termasuk perekonomian daerah, karena sektor pertanian berfungsi sebagai penyedia bahan pangan masyarakat, sebagai instrumen pengentasan kemiskinan, penyedia lapangan kerja, serta sumber pendapatan masyarakat. Dengan adanya pembuatan aplikasi E-padi ini dapat membantu orang yang ini memulai bertani dan generasi muda untuk mengetahui bagaimana proses bertani. Problematika yang dialami saat ini semakin menurunnya jumlah petani yang ada diIndonesia dan kurangnya minat anak muda untuk bertani seiring arus modernisasi sehingga menjadi petani tidak lagi menjadi pilihan mereka. Metode yang dilakukan dalam penelitian kali ini adalah metode waterfall. Metode waterfall merupakan model pengembangan sistem informasi yang sistematik dan sekuensial. Metode Waterfall memiliki 5 tahapan yaitu Requirement, Design, Implementation, Integration \& Testing, Operation \& Maintenance. Pembahasan menjelaskan tentang bagaimana awal mula bertani bagi para pemula serta menampilkan hasil apa saja yang dibutuhkan ketika inggin menjadi petani. Aplikasi E-padi akan membantu para generasi muda atau para pemula yang ingin bertani secara terstruktur dan jelas.
\end{abstract}

Kata kunci: Aplikasi, Android, Pertanian

Abstract - The agricultural sector has a very important role in developing the national economy, including the regional economy, because the agricultural sector functions as a provider of food for the community, as an instrument of poverty alleviation, as a provider of employment opportunities, and as a source of community income. With the creation of the E-padi application, it can help people who have started farming and the younger generation to know how the farming process is. The problems experienced today are the decreasing number of farmers in Indonesia and the lack of interest of young people in farming along with the flow of modernization so that becoming a farmer is no longer their choice. The method used in this research is the waterfall method. The waterfall method is a systematic and sequential information system development model. The Waterfall method has 5 stages, namely Requirements, Design, Implementation, Integration \& Testing, Operation \& Maintenance. The discussion explains how to start farming for beginners and shows what results are needed when you want to become a farmer. The E-padi application will help the younger generation or beginners who want to farm in a structured and clear way.

Keywords: Application, Android, Agriculture,

\section{Pendahuluan}

Indonesia disebut sebagai negara agraris karena sebagian besar penduduknya bermata pencaharian sebagai petani[1]. Keberadaan petani menjadi penting begi negara agraris untuk turut serta berkontribusi dalam meningkatkan kesejahteraan masyarakat [2]. Pertanian mempunyai peranan yang sangat penting baik di sektor pemenuhan kebutuhan pokok, selain itu pertanian juga berperan besar dalam mendongkrak sektor sosial, sektor perekonomian dan sektor perdagangan [3]. Indonesia memiliki lahan pertanian yang luas, sumber daya alam beraneka ragam dan berlimpah serta memiliki tanah yang subur karena mendapatkan banyak sinar matahari dan curah hujannya tinggi[4]. Jumlah penduduk yang semakin bertambah maka semakin menikat juga kebutuhan pokok dan kebutuhan pangan. Pertanian menunjang seluruh kebutuhan bahan pangan, bahan baku industri, atau sumber energi dan juga sebagai penghasil devisa yang relatif besar [5], Apabila pembangunan pertanian disuatu negara baik maka perekonomian negara akan stabil [6]. Kemajuan ilmu pengetahuan dan teknologi memiliki pengaruh yang sangat besar dalam berbagai bidang kehidupan manusia. Semakin berkembangnnya zaman, lmu pengetahuan dan teknologi semakin canggih dan mendukung terciptanya teknologi-teknologi baru [7]. Teknologi telah mempengaruhi kehidupan ini dan tidak bisa dihindari, karena IPTEK memberikan banyak manfaat dan memudahkan pekerjaan[8]. Berkembangnya TI (teknologi 
informasi) memudahkan manusia untuk mengakses informasi kapanpun dan dimanapun[9]. Perkembangnya teknologi informasi (IT) memberikan perubahan signifikan kepada kehidupan masyarakat sehari-hari. Seperti yang dilihat masyarakat sangat akrab perangkap teknologi, hampir semua golongan masyarakat mempunyai gadget dan digunakan dalam kehidupan sehari-hari [10].

Aplikasi android adalah software untuk perangkat mobile yang mencakup sistem oprasi, berkembang pesat di seluruh ekosistem seluler[11]. Dalam aplikasi ini diusahakan dapat membantu meningkatkan minat generasi muda untuk bertani dan meningkatkan pengetahuan tentang pertanian. Tujuan utama dari pembuatan aplikasi ini untuk meningkatkan pengetahuan dan minat anak muda untuk bertani secara detail dan terstruktur[12]. Oleh karena itu, dengan adanya aplikasi ini akan dapat membantu dan memberikan informasi bagi para generasi muda agar minat untuk bertaninya tidak luntur akan zaman.

\section{Metodologi Penelitian}

Metode yang dilakukan dalam penelitian ini adalah metode waterfall. Metode waterfall merupakan model pengembangan sistem informasi yang sistematik dan sekuensial. Metode Waterfall memiliki tahapan-tahapan sebagai berikut:

1. Requirement

Pada tahap awal ini kami mengumpulkan informasi yang dibutuhkan melalui hasil wawancara kepada petani yang kemudian didefinisikan secara rinci dan berfungsi sebagai spesifikasi sistem[13].

2. Software design

Pada tahap ini, Perancangan perangkat lunak melibatkan identifikasi dan penggambaran abstraksi sistem dasar perangkat lunak dan hubungannya.

3. Implementation

Tahap ini, dimana hasil dari desain perangkat lunak diterjemahkan ke dalam bahasa pemrograman.

4. Integration and system testing

Unit-unit individu program atau program digabung dan diuji sebagai sebuah sistem lengkap untuk memastikan apakah sesuai dengan kebutuhan perangkat lunak atau tidak. Setelah pengujian, perangkat lunak dapat dikirimkan ke customer[14].

5. Operation \& Maintenance

Tahapan terakhir adalah pengoperasian dan perbaikan dari aplikasi, perbaikan terhadap kesalahan yang ditemukan pada aplikasi setelah digunakan oleh user[9].

\subsection{Penggunaan Flutter}

Flutter adalah software yang digunakan untuk membangun aplikasi E-padi menjadi sebuah platform (iOs, Android) dengan menggunakan bahasa pemrograman dart dan satu basis kode. Flutter pertama di namai dengan "Sky" di jalankan dengan operasi sistem Android. Flutter bertujuan untuk dapat merender grafis secara cepat dan konsisten.

\subsection{Figma}

Figma digunakan untuk mendesain atau membuat UI aplikasi e-padi sebelum aplikasi E-padi menjadi sebuah program android. Aplikasi seluler Figma untuk Android dan iOS memungkinkan melihat dan berinteraksi dengan prototipe Figma. Figma dengan mudah dan secara real-time dapat di proses pada perangkat seluler. Kumpulan fitur Figma berfokus pada penggunaan dalam antarmuka pengguna dan desain pengalaman pengguna, dengan penekanan pada kolaborasi waktu nyata. Sebagai digital design and prototyping tool, Figma memudahkan kolaborasi dalam mendesain website, apps, serta berbagai komponen user interface lainnya karena bekerja di cloud dan bisa diakses via browser dari mana saja selama ada laptop dan internet.

\subsection{Visual Studio Code}

Visual studi code digunakan sebagai text editor untuk mengedit dan membuat source program. Visual Studio Code merupakan penyunting kode-sumber yang dapat digunakan dalam beragam bahasa pemrograman, termasuk Java, JavaScript, Go, Node.js, Python dan C++. Salah satu fitur terkemuka dari VSCode adalah kemampuan untuk membuat ekstensi yang menambahkan dukungan untuk bahasa baru, tema, dan melalukan analisis kode statis, dan menambahkan linter kode menggunakan Protokol Server Bahasa.

\section{Hasil Dan Pembahasan}

Pembahasan kali ini kami membuat flowchart terlebih dahulu, bisa dilihat gambar 3, user membuka aplikasi e-padi yang menampilkan fitur home atau bisa juga memilih apakah ingin masuk ke fitur berita atau fitur informasi, Jika memilih ya pada fitur informasi maka akan muncul beberapa informasi, user juga dapat memilih 
ingin melihat informasi tentang sumber-sumber materi, deskripsi aplikasi, nama tim pembuat, dosen yang terlibat, atau info unism. Jika memilih tidak maka user akan diarahkan kembali ke fitur home dari aplikasi.

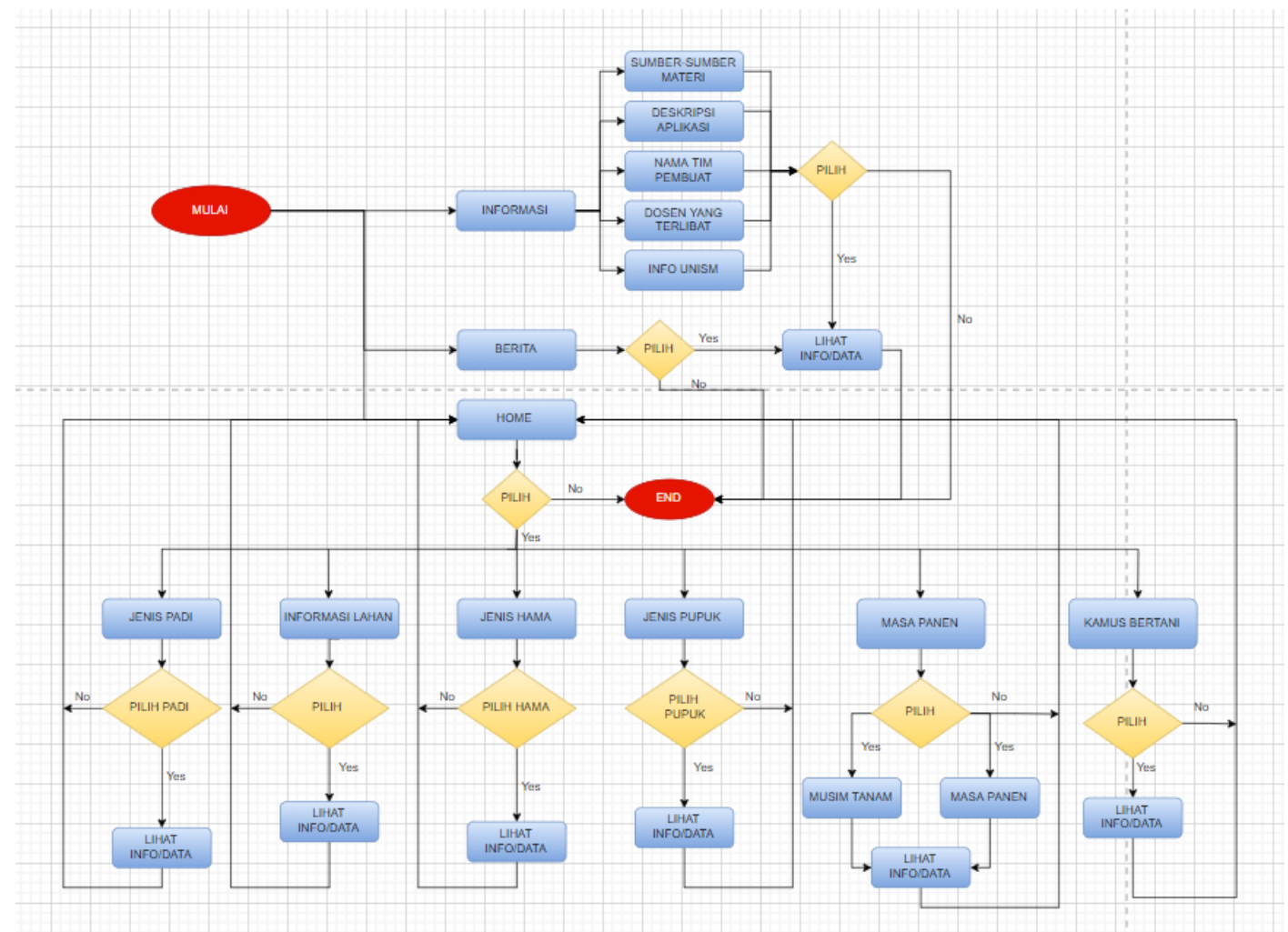

Gambar 1. Flowchart

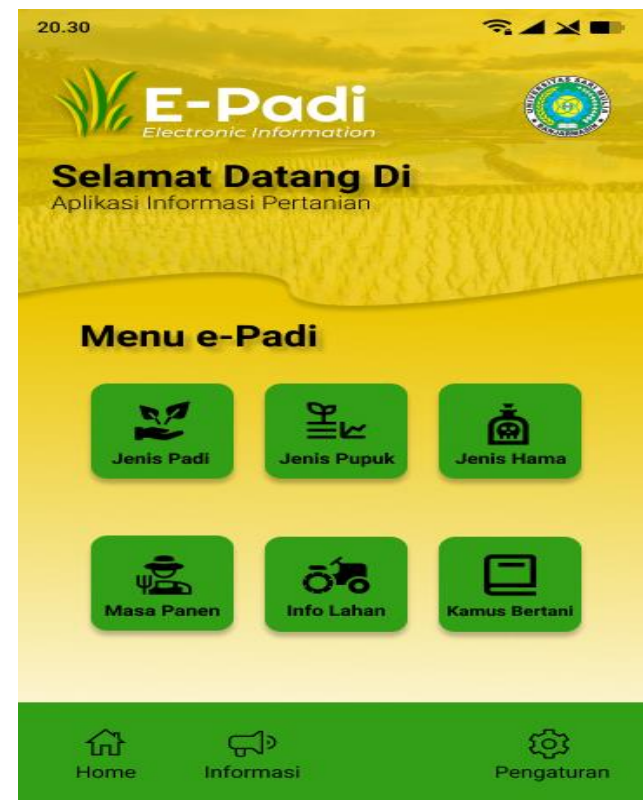

Gambar 2. Tampilan awal aplikasi e-padi 


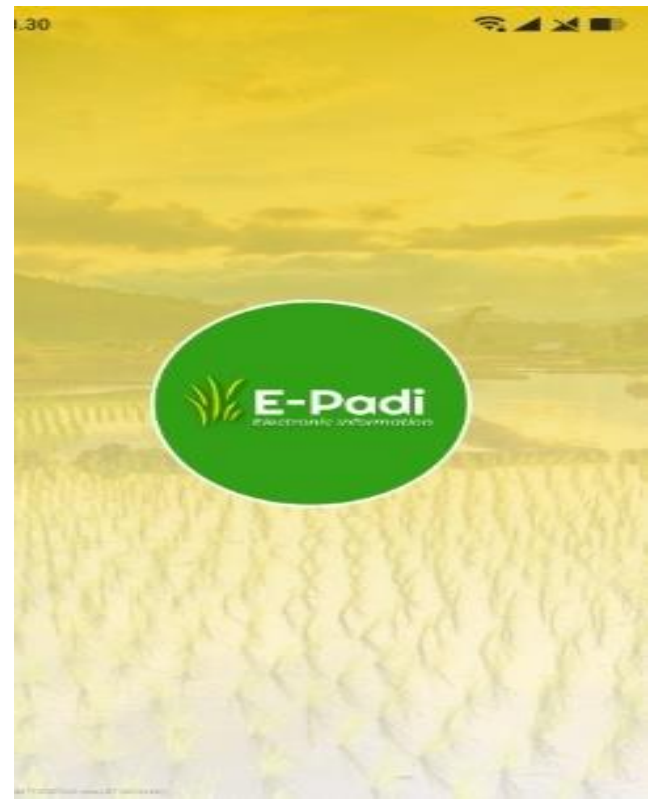

Gambar 3. Menu e-padi

Pada gambar 4 menampilkan tampilan awal/loding dari aplikasi E-padi. Pada gambar 5 menunjukan tampilan setelah kita tekan logo E-padi maka akan muncul menu-menu yang ada di aplikasi E-padi, dan ini adalah menu home terdapat beberapa menu lagi yang bisa digunakan pengguna aplikasi E-padi untuk mendapatkan informasi tentang pertanian seperti menu jenis padi, menu jenis pupuk, menu jenis hama, menu masa panen, menu info lahan dan menu kamus bertani.

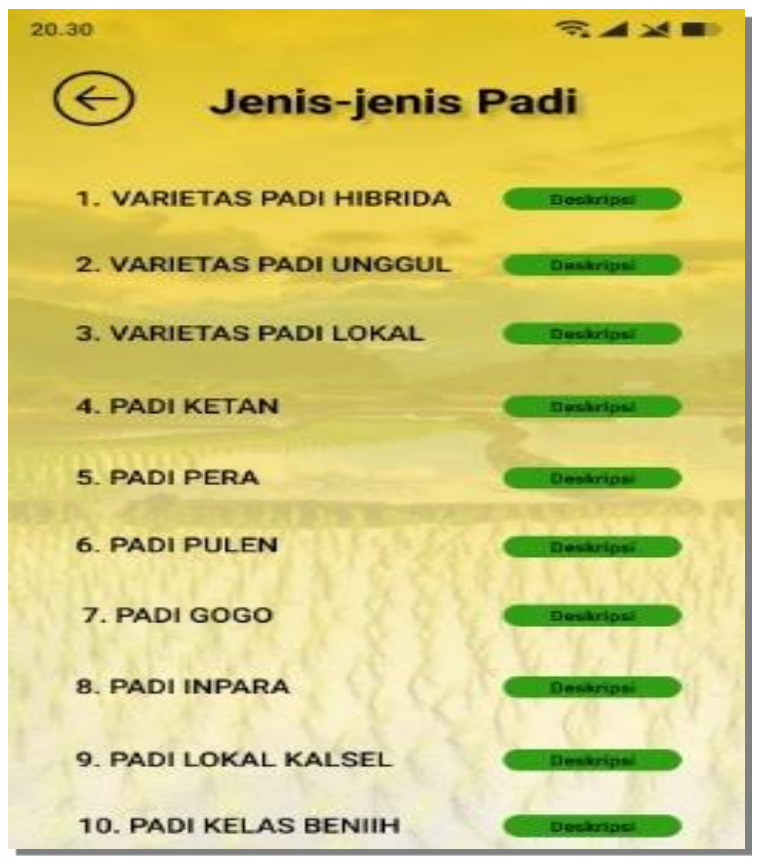

Gambar 4. Menu jenis-jenis padi 


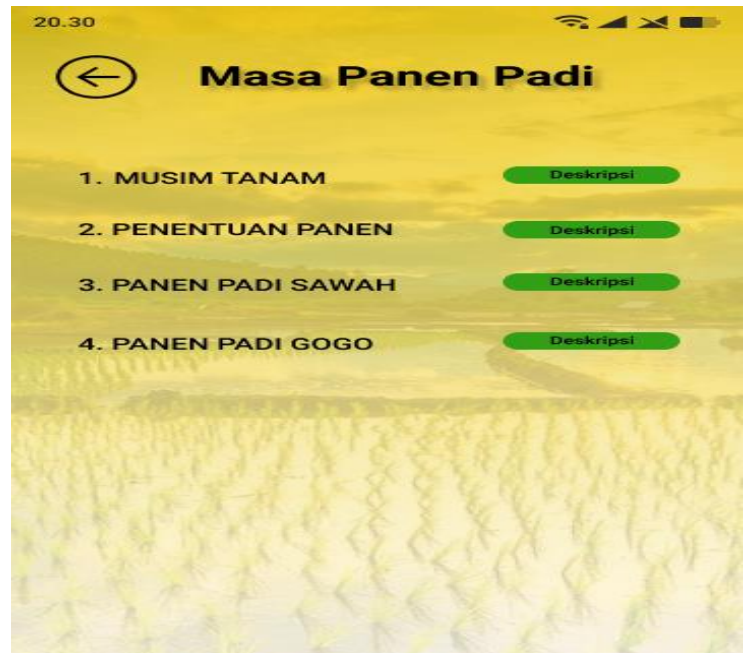

Gambar 5. Masa panen padi

Pada gambar 6 menunjukan tampilan setelah kita memilih menu jenis padi, didalam nya terdapat informasiinformasi tentang jenis-jenis padi dan Menjelaskan tentang berbagai macam Jenis padi yang berkualitas, bagus untuk gunakan dalam bertani, mejelaskan tentang keunggulan dan kekurangan dari jenis padi tersebut.

Pada gambar 7 diatas, adalah tampilan menu panen padisetelah kita memilih menu masa panen didalam nya terdapat beberapa pilihan seperti menjelaskan tentang musim tanam waktu tertentu yang dijadikan sebagai tahap pemulaan menanam. Penentuan waktu panen menjelaskan tentang waktu panen padi yang tepat untuk dipanen. Panen padi Sawah menjelaskan tentang panen dilakukan dengan mengetahui tanda-tanda yang terjadi pada padi disawah. Panen padi Gogo menjelaskan tentang panen padi dengan melihat ciri-ciri yang nampak yang siap panen.

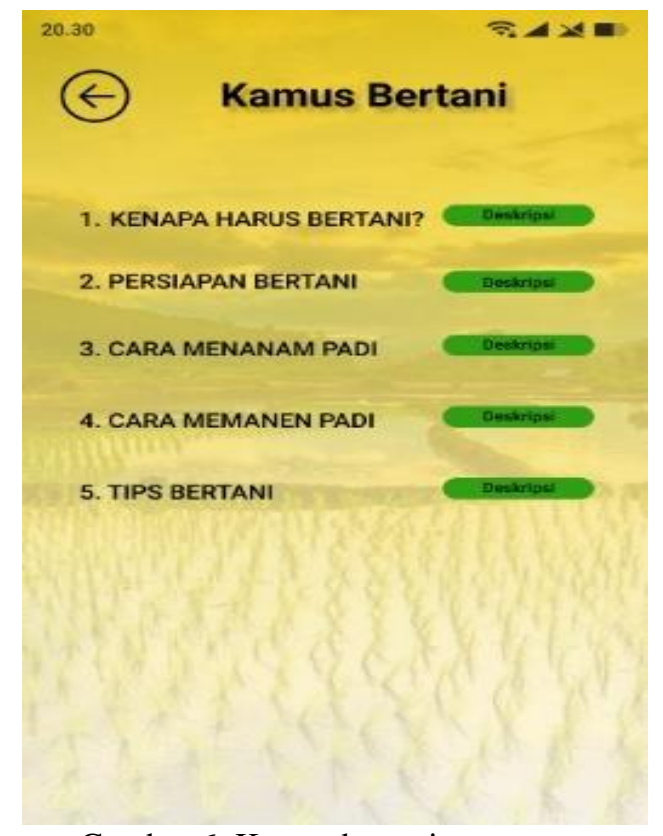

Gambar 6. Kamus bertani

Pada gambar 8 diatas, adalah tampilan setelah pengguna memilih menu dari kamus bertani didalam nya berisi tentang penjelasan Tentang Kenapa kita harus bertani, persiapan bertani, bagaimana cara menanam padi, bagaimana cara memanen padi dan tips Bertani yang cocok sekali untuk pemula. 


\section{Kesimpulan}

Dengan ini kesimpulannya bahwa Aplikasi E-padi Berbasis Android membantu masyarakat atau para pemula yang sedang mencari informasi tentang pertanian secara jelas dan terstrukur. Aplikasi E-Padi ini memuat beberapa fitur antara lain yaitu informasi seputar jenis padi, jenis pupuk, info lahan, jenis hama, masa panen dan juga berita terupdate tentang pertanian mempermudahkan dalam bertani. Aplikasi e-padi ini akan terus dikembangkan dengan harapan pada masa depan jumlah petani di Indonesia dapat meningkat dan pekerjaan pada sektor pertanian dapat menjadi pilihan utama generasi muda dalam membangun masa depan.

\section{Daftar Pustaka}

[1] F. SETYADI, "12.40.0211 Febri Setyadi - BAB I," Subj. WELL-BEING PADA PETANI MUDA, pp. 1$8,2017$.

[2] N. Ahmad and Iskandar, "Metode Forward Chaining untuk Deteksi Penyakit Pada Tanaman Kentang," JINTECH J. Inf. Technol., vol. 1, no. 2, pp. 7-20, 2020.

[3] A. J. Najib, "Transfer Pada Produksi Padi Di Kabupaten,” no. December 2017, pp. 582-590, 2019.

[4] R. Saydi, "Monitoring Curah Hujan dan Kelengasan Tanah Lahan Pertanian Menggunakan Sensor Berbasis Internet of Things (IoT) sebagai Dasar Pertanian Presisi," J. Ilm. Teknol. Pertan. Agrotechno, vol. 6, no. 1, p. 25, 2021.

[5] E. R. Onainor, “済無No Title No Title No Title,” vol. 1, pp. 105-112, 2019.

[6] R. D. Puspitasari, "Pertanian Berkelanjutan Berbasis Revolusi Industri 4.0," J. Layanan Masy. (Journal Public Serv., vol. 3, no. 1, p. 26, 2020.

[7] J. Volume, N. Tahun, J. Pendidikan, F. Mulyani, and N. Haliza, "Research \& Learning in Faculty of Education Analisis Perkembangan Ilmu Pengetahuan dan Teknologi ( Iptek ) Dalam Pendidikan,” vol. 3, 2021.

[8] R. Komalasari, "Manfaat Teknologi Informasi Dan Komunikasi Di Masa Pandemi Covid 19," Tematik, vol. 7, no. 1, pp. 38-50, 2020.

[9] M. Munawir et al., "Penerapan Sistem Informasi Pendataan Penerima Dana Program Keluarga Harapan pada Gampong Beurawe Kecamatan Kuta Alam berbasis Web GIS," J. Serambi Eng., vol. 6, no. 3, 2021.

[10] D. Ramayanti, W. Gunawan, and I. I. Faishal, "Implementasi QR-Code pada Aplikasi E-Market Mandiri untuk Pemberdayaan Ekonomi Kreatif Berbasis Android," J. Inform., vol. 8, no. 1, pp. 34-40, 2021.

[11] Muhammad Nauval El Ghiffary, Tony Dwi Susanto, and Anisah Herdiyanti, "Analisis Komponen Desain Layout, Warna, danKontrol Pada Antarmuka Pengguna Aplikasi MobileBerdasarkan Kemudahan Penggunaan(Studi Kasus: Aplikasi Olride)," J. Tek. ITS, vol. Vol. 7, no. 1, p. A 143-A 148, 2018.

[12] M. Fadhli et al., "Perancangan aplikasi ujian mahasiswa baru pada universitas serambi mekkah berbasis web 123," vol. 2, no. 2, pp. 202-209, 2019.

[13] E. Erdiwansyah, M. Munawir, S. Susmanto, Z. Zulfan, and T. Hidayat, "Sistem Pendukung Keputusan Managemen BUMG Gampong Lambeugak Kecamatan Kuta Cot Glie Aceh Besar,” BAKTIMAS J. Pengabdi. pada Masy., vol. 3, no. 3, pp. 93-100, 2021.

[14] S. Susmanto, M. Munawir, E. Erdiwansyah, Z. Zulfan, and D. Setiyadi, "Perancangan E-Voting pemilihan Kepala Desa untuk Transparansi Informasi di Kecamatan Lueng Bata Kota Banda Aceh,” J. Serambi Eng., vol. 7, no. 1, 2022. 